\title{
Early Coastal Fiber Technology from the Caleta Vitor Archaeological Complex in Northern Chile
}

\author{
Tracy Martens and Judith Cameron
}

\begin{abstract}
The marine subsistence economy of the prehistoric people of northern Chile was heavily reliant on fiber technology for the components of nets, lines, and tethers. Despite the significance and the remarkable preservation of fiber artifacts along the arid Atacama coastline, these components have received little direct attention. This case study of fiber artifacts from the Caleta Vitor archaeological complex is the first broad overview of techniques, material usage/preference, and fiber-processing conventions at a northern Chilean Archaic period site. The data presented in this paper indicate gradual change in material preferences over time, shifting from locally available vegetal fiber, which dominates the Archaic period, with small amounts of camelid fiber, to the predominance of camelid fiber in the Late Formative period. This change coincides with the appearance of more complex weaving techniques indicating participation in the previously established textile tradition proposed by Ulloa (2008) as stretching from the Azapa Valley to the Loa River.
\end{abstract}

Keywords: Caleta Vitor archaeological complex, northern Chile, Chinchorro, Formative period, archaeological textiles, fiber processing

La economía de subsistencia marina de las poblaciones prehistóricas del norte de Chile dependía, en gran medida, del trabajo de la fibra para la elaboración de redes, líneas de pesca y cuerdas. A pesar de la importancia y la notable preservación de los artefactos de fibra a lo largo de la costa árida de Atacama, estos elementos de cordelería han recibido poca atención. Este trabajo, sobre los artefactos de fibra del complejo arqueológico de Caleta Vitor, constituye la primera descripción general de la técnica, del uso/preferencia de materiales y de las convenciones sobre el procesamiento de la fibra en un sitio arqueológico del período arcaico en el norte de Chile. Asimismo, se consideran las técnicas de tejido más complejas que aparecen en el período Formativo tardío, que consolidan la tradición textil previamente establecida, propuesta por Ulloa (2008), que se extiende desde el Valle de Azapa hasta el Río Loa.

Palabras clave: complejo arqueológico de Caleta Vitor, norte de Chile, Chinchorro, período Formativo, textiles arqueológicos, procesamiento de fibra

\section{The Significance of Fiber Technology}

$\mathrm{F}$ Tor millennia in northern Chile, fiber technology played a central role in economic life, providing not only the basic components of clothing and the matting that sheltered the living and shrouded the dead but also the basic tools on which the marine exploitation strategies of the Chinchorro and their successors depended. For these subsistence activities, people relied heavily on reeds that grew abundantly along the quebradas that drain to the Pacific coast. In the early years of their settlement of the coast the Chincorro learned how to weave fine, shredded reed fiber to make a wide range of artifacts, including mats for roof thatching; clothing such as breechcloths and fringe skirts or faldellines; funerary bundles; and hunting, fishing, and gathering implements such as chinguillo, reed nets. Twisted camelid wool, cotton fibers, and leather were also integrated into this industry (Santoro et al. 2005).

Despite its broad application, fiber technology has not received a great deal of attention in this pivotal area, where the dry conditions of

Tracy Martens $\square$ College of Asia and the Pacific, Australian National University, Canberra ACT 2600, Australia (martens. tracy@gmail.com, corresponding author)

Judith Cameron $~$ College of Asia and the Pacific, Australian National University, Canberra ACT 2600, Australia

Latin American Antiquity 30(2), 2019, pp. 287-299

Copyright (C) 2019 by the Society for American Archaeology doi:10.1017/laq.2018.78 
the Atacama have made possible the excellent preservation of perishable artifacts. In other parts of the Andes-Paloma, Monte Verde, Quebrada Jaguay, Guitarrero Cave, and La Yerba-pioneering investigations (Adovasio 1997; Adovasio and Lynch 1973; Adovasio and Maslowski 1980; Beresford-Jones et al. 2017; Bird 1963; Jolie et al. 2011; Sandweiss et al. 1998; Ulloa 1981a, 1981b, 2001) of fiberbased materials from archaeological contexts have highlighted the significance and antiquity of fiber technology in the Americas and the role of these artifacts in the rise of complex societies. These investigations have also produced important evidence of maritime adaptations and bolstered claims of Pleistocene occupation of the high Andes.

The techniques of twisting, spinning, plying, and knotting are fundamental to fishing: they are required to make lines that attach to fishhooks and net weights, as well as basketry containers for fish and other marine resources. Archaeologists have established that fishing technology was in use along the Peruvian coast from the late Pleistocene/early Holocene; it was probably introduced by the earliest migrants to northern Chile more than 10,000 years BP (Carter 2016; Sandweiss et al. 1998; Santoro et al. 2017a) and quite possibly when the Andean coast was first settled in the late Pleistocene (Keefer et al. 1998). The distribution of diagnostic items of material culture across some $500 \mathrm{~km}$ of coastline at Archaic period sites between the Ilo and Loa Rivers shows the extent of Chinchorro mobility (Arriaza 2008; Carter 2016; Marquet et al. 2012; Santoro et al. 2012; Standen et al. 2017). The most enduring item produced by the Chinchorro is the burial mat that remained unchanged over thousands of years: it served as shrouds from at least $9000 \mathrm{BP}$ through to the final stages of decline of the Chinchorro culture in the Early Formative period (ca. 3600 BP), despite many other changes in mortuary practices (Arriaza 1995; Arriaza et al. 2005; Aufderheide et al. 1993; Cassman et al. 2008). These iconic items were made using a technique called twining, considered to be a precursor to loom weaving (Cassman et al. 2008; Doyon-Bernard 1990)—a later technological development attributed to contact with highland groups arriving in the area during the Formative period by 3500 BP (Carter 2016:243; Ulloa 1981a).

Knowledge of Archaic fiber technologies on Chile's northern coast has been obtained primarily from burial contexts. Despite studies of fishing technology demonstrating the prevalence and antiquity of cordage (Bird 1943; Carter 2016; Sandweiss 2008; Sandweiss et al. 1998; Schiappacasse and Niemeyer 1984), there is practically no information about the use of fibers for other domestic purposes. Cassman and colleagues (2008) point out that, although the production of reed mats is commonly noted at burial sites, their expert construction suggests that they had a much broader application. Even so, these items have received limited attention and, in some instances, were not even collected during excavation. As a result, fiber technology before the introduction of weaving by highland groups remains undocumented. Except for Cassman and colleagues' (2008) investigation of burial mats, there are no detailed analyses of fiber technology at Chinchorro sites.

\section{Background}

The coastal region of northern Chile (Figure 1) was occupied during the Early Holocene by marine hunter-gatherers who became known as the Chinchorro, famous for their distinctive mummification techniques evidenced as early as 7500 BP and continuing into the Formative period (ca. 4000-1500 BP), when the culture went into decline (Arriaza 1995, 2008; Bittmann and Munizaga 1976; Marquet et al. 2012; Roberts et al. 2013). The rich biota of the Pacific coast of northern Chile enabled the Archaic marine hunter-gatherers and their successors to develop a semi-sedentary mobility pattern, which provided food security even after circa 10,000 BP when a prolonged drought made the intermediate depression, the core of the Atacama Desert, inhospitable (Gayo et al. 2012; Latorre et al. 2013; Santoro et al. 2017b). The inhabitants of Caleta Vitor remained heavily dependent into the Late period (600-476 BP) on marine proteins, which they complemented by exploiting or trading a limited range of terrestrial resources for both food and craft production (Aufderheide et al. 1988; Castro 2014; King et al. 2018; 


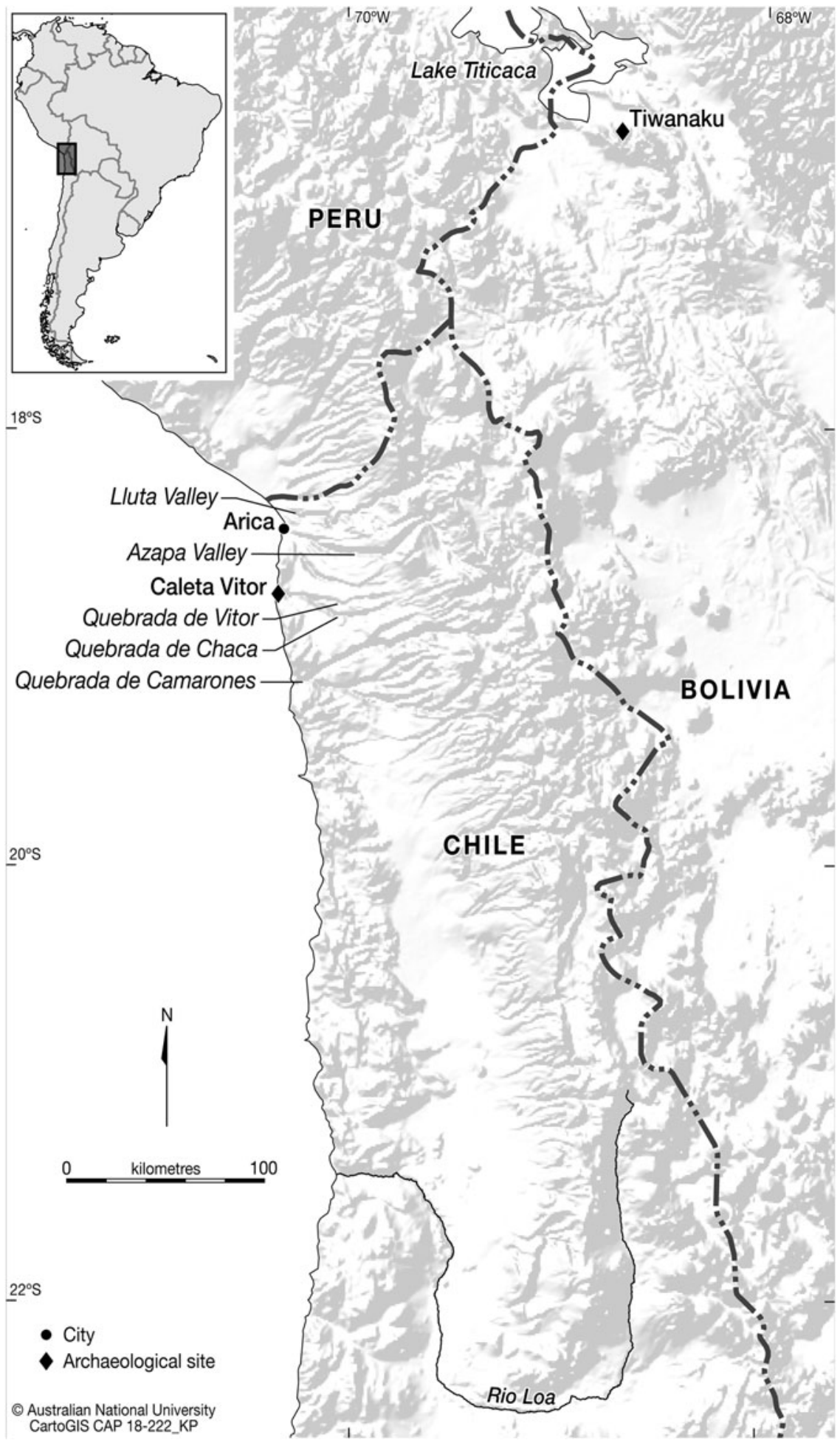

Figure 1. Map showing the archaeological sites, modern cities, waterways, and quebradas mentioned in the article (ANU Cartography). 
Poulson et al. 2013; Rivera 2008; Roberts et al. 2013; Santoro et al. 2012, 2017a; Tieszen and Chapman 1992). These subsistence and craft economies have been described as "stable and local" (Bland et al. 2017:282), with inhabitants exploiting the same locally available, raw resources for both food and pottery production over an extended time period (Carter 2016; Roberts et al. 2013).

The final phase of the Chinchorro culture (4000-3600 BP), during the beginning of the Formative period, is marked by changes in burial practices and agricultural products, textiles, and exotic trade goods (Carter 2016; King et al. 2018; Rivera 1991, 2008; Roberts et al. 2013; Santoro et al. 2017a). Long-distance trading networks were made possible by highland camelid caravans that facilitated the movement of goods to the coast and back (Carter 2016). Despite the influx of trade goods and people from the highlands, the Loa region, and possibly other, more distant areas, as well as the continuation of many aspects of their material culture, this is considered the final phase of Chinchorro culture (Table 1).

The Formative Period (4000-1500 BP) is one of change and considered to be the "first stage of Andean tradition in northern Chile" (Rivera 1991:21), with the arrival of trade goods and people from the highlands including pottery (ca. $3000 \mathrm{BP}$ ) and hallucinogenic drug paraphernalia like snuff trays (McRostie 2014; McRostie et al. 2017; Muñoz et al. 2016; Núñez and Santoro 2011; Rothhammer and Dillehay 2009; Ulloa 2008). The impact of these external pressures appears to have varied across the region (Santana Sagredo et al. 2015; Valenzuela et al. 2015). Some sites adopted pastoral and agricultural subsistence strategies (particularly in the Lluta Valley) whereas others remained focused marine hunter-gatherers (Santoro et al. 2017a).

\section{The Archaeological Context}

The Caleta Vitor complex lies at the Pacific coastal terminus of Quebrada de Chaca/Vitor in the Atacama Desert of northern Chile, approximately $50 \mathrm{~km}$ south of the Chilean-Peruvian border. The site consists of rock art, middens, occupation areas, and burials. Before recognizable, scientific archaeological work commenced in this region, interest focused largely on mummified human remains, which museum representatives from around the world took to form their collections (Carter 2016). Max Uhle's 1919 investigations and subsequent establishment of a chronological sequence for Arica (Uhle 1974) marked the beginning of earnest archaeological work in northern Chile (Carter 2016). This work was followed by Junius Bird's (1943) extensive excavations at coastal sites from Arica to Taltal, from which he concluded that the prehistoric people of this region had a marine-focused economy. These early chronologies were impressively constructed without the benefit of radiocarbon dates. At that time, occupation of the region was thought to span just 2,000 years. The greater antiquity of the region only began to be recognized in the early 1990s, when occupation of the general area was dated to the Pleistocene (Arriaza 1995; Auferheide et al. 1993; Núñez et al. 2002; Rivera 1991; Sandweiss et al. 1998; Santoro et al. 2005). At Acha, which lies $5.4 \mathrm{~km}$ inland from Arica, occupation is now dated to the Early Holocene (Standen and Santoro 2004). Based on extensive bioarchaeological work, isotopic research, and studies of genetically controlled dental traits, scholars have now established the origin of the people known as the Chinchorro, shown the persistence of the marine economy that supported them, and demonstrated the evolution of what is now recognized as the world's oldest human mummification procedures (Arriaza 1995; Arriaza et al. 2005; Poulson et al. 2013; Roberts et al. 2013; Rothhammer and Dillehay 2009; Sutter 2000).

In this article, we focus on fiber data from excavations undertaken between 2008 and 2010 at Caleta Vitor (Carter 2016), the first documented archaeological excavations of the site. Although Carter's excavations were conducted primarily to collect in situ material culture and attempted to avoid graves that contained prestige and curated goods, he did encounter some graves that were intermingled with occupation areas. This report is therefore a record of fiber artifacts in regular domestic use, as well as burial items, in open coastal camps in northern Chile.

Carter (2016) divided the Caleta Vitor complex into seven zones: CV1-CV7 (Figure 2). 
Table 1. Radiocarbon Assays from the Caleta Vitor Archaeological Complex.

\begin{tabular}{lllllc}
\hline Lab No. & Context & Material & $\begin{array}{l}\text { Age BP } \\
\text { (cal 2 sigma) }\end{array}$ & Period & Phase \\
\hline UGAMS10509 & CV1/3/25 & Calyx & $6411-6631$ & Middle Archaic & Chinchorro \\
UGAMS10508 & CV1/3/14 & Calyx & $6496-6717$ & Middle Archaic & $(8000-6000$ BP) \\
ANU31018-9189 & CV1/3/9 & Cane & $5664-5910$ & Late Archaic & \\
ANU31017-9188 & CV7/1/10 & Cane & $4839-5039$ & Late Archaic & Late Chinchorro \\
UGAMS10506 & CV1/2/13 & Calyx & $4437-4525$ & Late Archaic & (6000-4000 BP) \\
UGAMS10524 & CV7/1/6 & Calyx & $4094-4408$ & Late Archaic & \\
UGAMS10513 & CV2/1/39 & Cotton seed & $3346-3458$ & Early Formative & Final phase of Chinchorro \\
UGAMS10505 & CV1/2/6 & Algarrobo pod & $3263-3360$ & Early Formative & culture (4000-3600 BP) \\
& & & & & Azapa (4000-2500 BP) \\
UGAMS10507 & CV1/3/1 & Algarrobo pod & $2484-2697$ & Late Formative & Alto Ramirez (2500-1500 BP) \\
ANU31013-9185 & CV2/1/20 & Charcoal & $2363-2713$ & Late Formative & \\
UGAMS10510 & CV2/1/1 & Algarrobo pod & $1931-2129$ & Late Formative & \\
\hline
\end{tabular}

Note: Data from Carter (2016:219) and Roberts and colleagues (2013:2362).

Only CV1, CV2, and CV7 produced Archaic and Formative period fiber artifacts. CV1 was the largest of the three preceramic midden and occupation areas: it produced several burials, including one reed-wrapped extension featuring the remains of bird skin and feather embellishments (the burial was left in situ and reburied later). This burial led Carter to conclude that the material culture in this area was Chinchorro in origin. Radiocarbon dates (Table 1) confirm Carter's assessment that CV1CV3 span the Archaic and Early Formative periods. CV2, with its well-defined stratigraphy in which both ceramic and preceramic layers contain burials, was identified by Carter as a midden and occupation area dated between the Early and
Late Formative periods (Table 1). The area was heavily disturbed by military activities and looting and is separated from CV4 by a road on its northern boundary. CV7 is the northernmost zone, described as a low-density midden with several burials that were reburied at the time of excavation (Carter 2016). Materials from CV7 are dated to the Late Archaic period (see also Latorre et al. 2017; Santoro et al. 2017a for chronology on these seven archaeological zones).

Fiber artifacts were first found in Middle Archaic period deposits, whereas indirect evidence for cordage technology was recovered from layers dating to the Early Archaic. A fine shell bead was found in the layer above CV3/1/

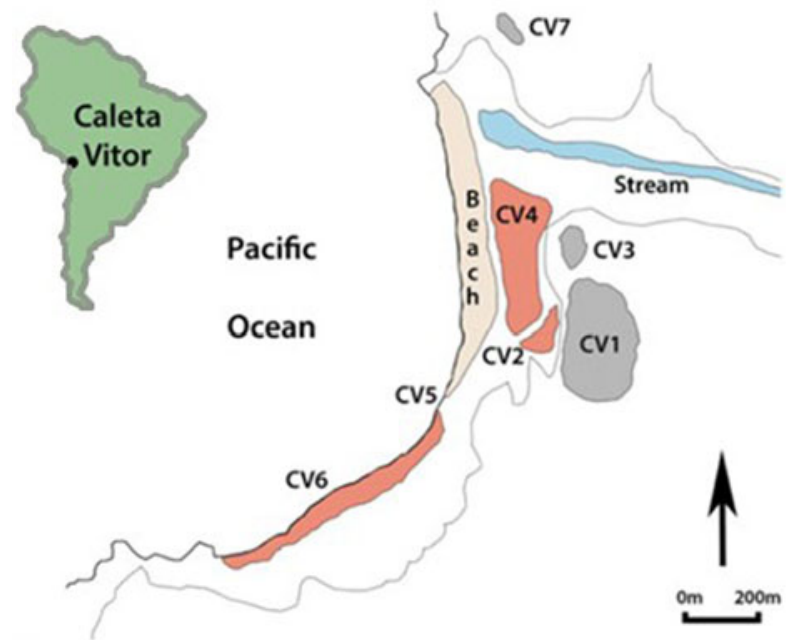

Figure 2. Map showing the seven sectors designated by Carter during the 2008-2010 excavations and important topographic features at the Caleta Vitor archaeological complex. 
30, dated 8662-9487 BP (ANU31014-9186). The bead, which measured $4.7 \mathrm{~mm}$ in diameter and was $1.4 \mathrm{~mm}$ thick with a $2.3 \mathrm{~mm}$ hole, was almost certainly suspended on a cord. Bones from very small fish species identified as net caught were found in large numbers in the earliest Archaic period unit (CV3/1/31), dated 92719487 BP. As Carter explains, nets would have been necessary to catch the large numbers of very small sardines and anchovies (Engraulidae) represented in the unit. Other excavated species and small animals are also presumed to have been net caught.

\section{Methodology}

The fiber remains excavated from Caleta Vitor were analyzed in Arica, Chile, at de Laboratorio de Arqueología y Paleoambiente, Instituto de Alta Investigación (IAI), at the Universidad de Tarapacá (UTA), between March and May 2016. The techniques were identified and described in accordance with classifications devised by Adovasio (1977), Emery (1980), Wendrich (1991), Cassman (1997), Kuttruff and Strickland-Olson (2000), and Jolie and colleagues (2011). All items were initially inspected with the unaided eye, followed by examination under an Aven 26700-302 zipScope at 50X magnification. They were then photographed with a Canon $30 \mathrm{X}$ handheld digital camera. We measured the dimensions using digital and conventional calipers.

After dividing the items into three broad categories based on their material compositionanimal, vegetal, and cotton-we used a dissecting microscope at $400 \mathrm{X}$ magnification to verify identifications of the camelid and cotton fibers. Because the focus of the research was technical analysis of the fragments, we did not engage in archaeobotanical research, although this is planned for a future project. After determining the items' material composition, we analyzed their structural composition: we measured and recorded the number of elements and the twist, spin, ply, and reply (after Emery 1980:8-14). Once these basic characteristics were identified, we analyzed the fabric structures, documenting attributes such as condition, color, tightness, and the angle of twist. We calculated fabric density (Supplemental Table 1) scores where appropriate based on Cassman's (1997:87) formula: warp diameter/warps/unit + weft diameter/wefts/unit.

\section{Results and Discussion}

Altogether, we identified and recorded 546 fiber artifacts (Supplemental Table 2) from 38 excavation units assigned to the Middle Archaic, Late Archaic, Early Formative, and Late Formative periods, based on recently obtained radiocarbon dates (Table 1; after Carter 2016). The Middle Archaic unit (CV 1/3/10) produced the highest number of fiber artifacts $(n=226)$. Unfortunately, that unit was heavily disturbed by a rodent burrow that extended horizontally into the profile. Although the disturbance is described as discrete and not affecting the neighboring units (Christopher Carter, personal communication 2018), it raised questions about the provenance of the textile fragments found there. The disturbed context included not only hundreds of camelid fiber threads but also four small fragments of camelid wool textile (8285-1, 8285-2, $8285-3,8285-4$ ) ranging in size from $35 \mathrm{~mm} \mathrm{x}$ $24 \mathrm{~mm}$ to $10 \mathrm{~mm} \times 7 \mathrm{~mm}$. These seemingly precocious fragments (David Beresford-Jones, personal communication 2018) were similar to those encountered in the interlaced textiles from Guitarrero Cave (see the later discussion). We therefore obtained radiocarbon assays on three of the camelid fragments (8285-3, 8285-4, $8285-5)$, as well as on a thread (8285-6). The radiocarbon determinations confirmed that the artifacts were indeed out of sequence, belonging to the Late period (Table 2), and the artifacts from unit CV1/3/10 were subsequently reassigned and will be discussed in another article on the Late Horizon fiber artifacts from the site.

In total, $36.42 \%$ of the fragments from securely dated strata were camelid, confirming the high value placed on this species during the prehistoric period. The proportion of camelid fiber fragments steadily increases over the four periods, supplanting vegetal fiber in the Late Formative period as the most common material (Figure 3). Although small quantities of camelid fecal pellets were left at the Caleta Vitor site circa 3346-3458 BP, the absence of camelid bones in the collection, along with strong marine isotopic 
Table 2. Radiocarbon Dates for CV1/3/10 Camelid Fiber Artifacts, Late Horizon Period.

\begin{tabular}{llcc}
\hline Lab No. & Material & Radiocarbon Age (yr BP) & Age (cal BP)1 $\sigma$ \\
\hline WK47776 & Interlaced camelid fiber textile 8285-2 & $671 \pm 20$ & $560-650$ \\
WK-47777 & Interlaced camelid fiber textile 8285-3 & $654 \pm 17$ & $550-630$ \\
WK-47778 & Interlaced camelid fiber textile 8285-4 & $656 \pm 19$ & $550-640$ \\
WK-47779 & Camelid fiber thread 8285-6 & $573 \pm 18$ & $520-550$ \\
\hline
\end{tabular}

Note: Dates calibrated using Ox Cal v4 (after Bronk Ramsey 2017) r5 SHCal13 atmospheric curve (Hogg et al. 2013).

signatures in the human remains, indicates a dietary reliance on marine proteins that lasted through to the Late Holocene (Roberts et al. 2013). According to Carter (2016), the Chinchorro traveled up the quebradas $(<2,500 \mathrm{~m}$ above sea level) to wetter, more ecologically abundant ecosystems to hunt wild guanaco during the Middle and Late Archaic periods and engaged in exchange with highland groups circa $3500 \mathrm{BP}$. This interpretation is supported in northern Chile by evidence near Antofogasta that indicates that wild camelids were hunted for fibers and meat from the Early Holocene onward (Llagostera 1979).

A small proportion $(2.1 \%)$ of the fibers were identified as Gossypium barbadense (cotton) (Figure 4). Northern Peru is one of the origin centers for G. barbadense, and scholars previously noted in the appearance of cotton at preceramic northern Peruvian sites and identified cultivated cotton by 5490 BP (Dillehay et al. 2007). Significantly, the appearance of worked cotton at Caleta Vitor (CV1/3/2), below unit CV1/3/1 dated 2484-2697 cal BP, is pre-dated by cotton seed from CV2/1/39, dated 3358$3446 \mathrm{cal} \mathrm{BP}$, which itself is approximately 500 years later than the earliest appearance of the material on the Peruvian south coast, as identified at Otuma and dated $4150 \mathrm{cal}$ BP after the preceramic period (Beresford-Jones et al. 2017).

Cotton's exceptionally long staple makes it well suited for the production of fine, strong threads for fishing lines and nets. At Caleta Vitor, Carter identified large numbers of netcaught fish species from the Early Archaic period unit (CV3/1/31), dated 9271-9487 BP. As Carter deduced, nets would have been necessary to catch fish in such large numbers. Previous investigations on the coast of northern Chile did not provide any archaeological evidence of cotton use in domestic and ceremonial contexts during the Archaic period. Instead, it was posited that people only used camelid and vegetal fibers (Standen 1997, 2003; Standen and Santoro

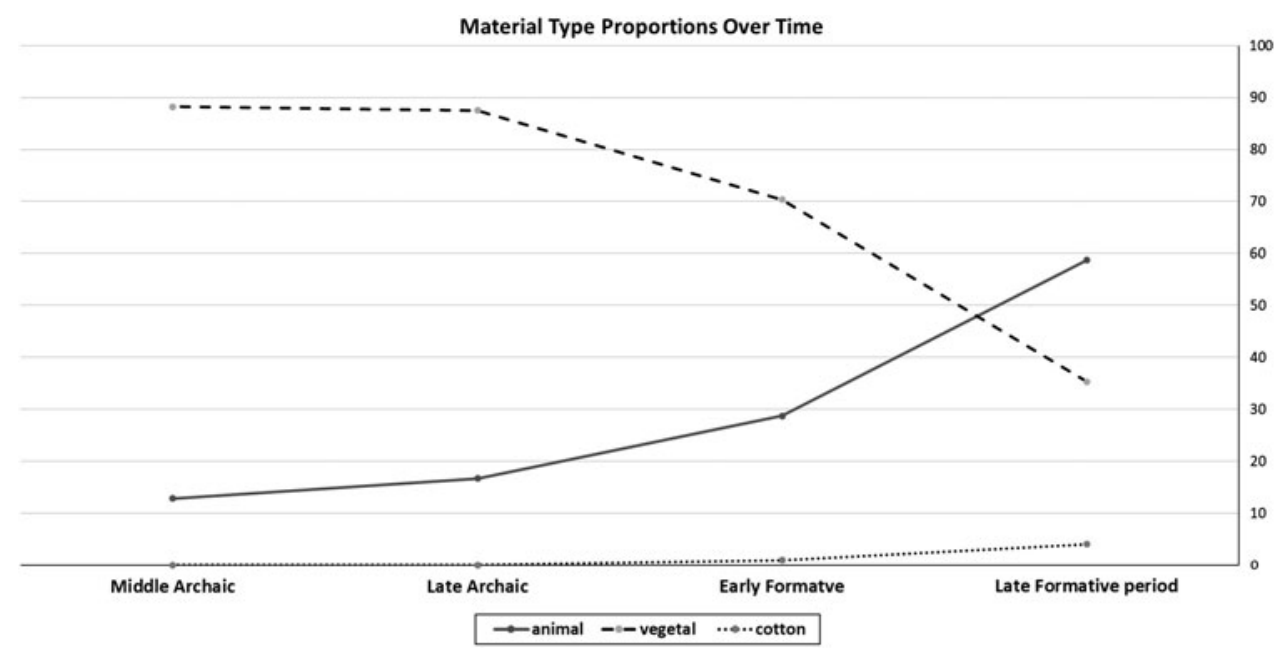

Figure 3. Material type proportions over time. 


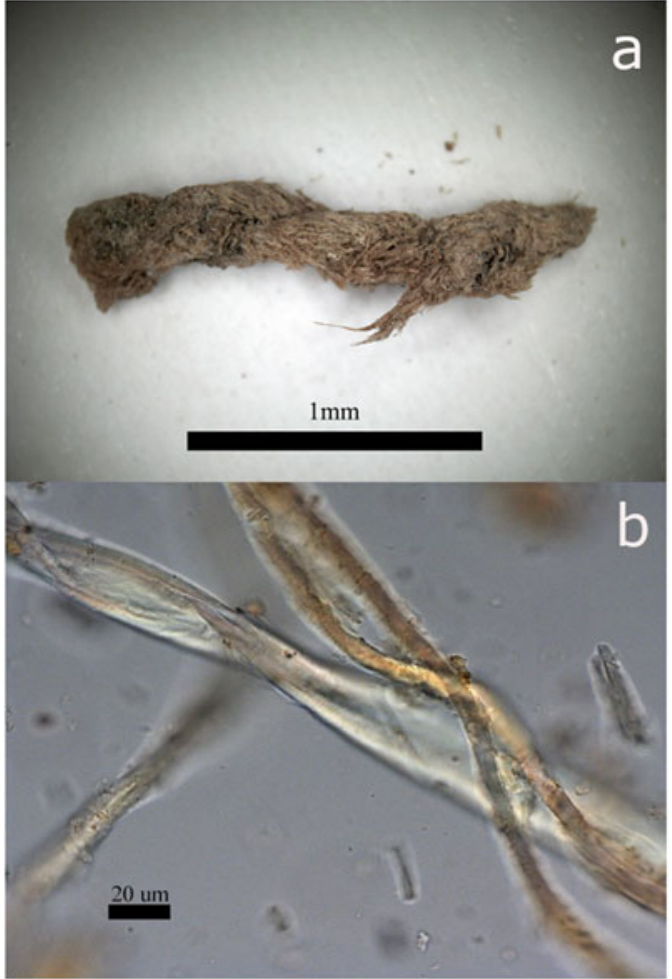

Figure 4. (a) Earliest cotton thread recovered from the Caleta Vitor archaeological complex; (b) The early cotton thread (a) at 400X magnification, showing diagnostic convolutions.

2004). After its initial appearance in the beginning of the Early Formative period, cotton was rarely found in subsequent sequences, with just six threads and one fragment of interlaced textile identified (see the later discussion). The absence or low occurrence of cotton could be explained by postdepositional factors, given that a conglomeration of unworked cotton from the same unit was in good condition. It was also apparent that the earliest cotton threads from the beginning of the Early Formative period were in a more degraded condition than the unworked cotton and the worked and unworked animal and vegetal materials from the same unit, requiring extreme care in handling. The lack of cotton could also be a result of a digenetic process affecting preservation in situ or to chemical or physical treatments of the material before deposition.

Vegetal artifacts are prominent throughout the sequence, eventually dropping off in the Late Formative period when camelid fiber becomes

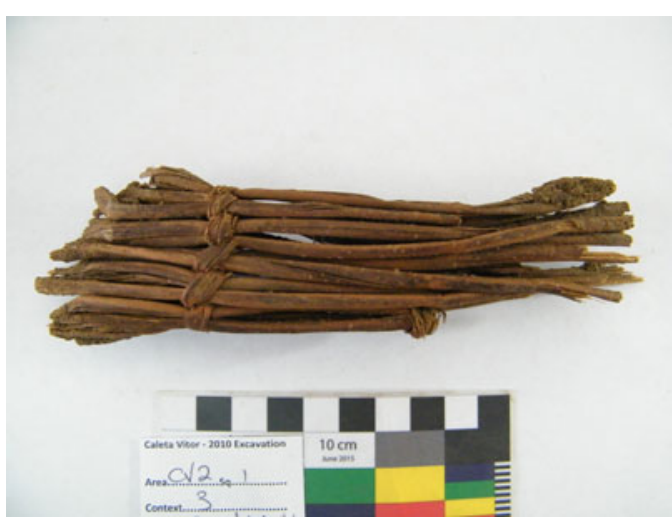

Figure 5. Small fragment of vegetal twining from CV2/1/3.

the most common material (Figure 3). Cassman and colleagues' (2008) comparative analysis of extant plants from the Lluta Valley and vegetal material from a Chinchorro burial shroud from the Azapa Valley indicates that the material was derived from a reed (sedge) belonging to the family Cyperaceae, most likely Scirpus sp.

\section{Structural Composition}

Twining is the simplest textile production technique identified in the collection (Figure 5). In total, 12 twined fragments were excavated from Middle and Late Archaic sequences and from Late Formative units. This technique requires no tools and is generally considered to be one of the earliest methods for constructing fabrics in the world and, as mentioned, the precursor to loom weaving (Bird 1963; Doyon-Bernard 1990; Emery 1980; Ulloa 2008). Twining requires two sets of elements: one passive, one active. Semi-rigid strips of vegetal materials that constitute the warp (passive, structural element) are laid on the ground, while flexible cordage constitutes the weft (active element) that passes over and under each of the warp strips (Adovasio 1977). Caleta Vitor's fragments were all examples of spaced twining and z-twining. This structural element appears to have received little or no processing. Twining differs from loom weaving in the absence of a wooden frame and the orientation of the maker's body. The warps are oriented parallel to the long axis of the maker's body, rather than at right angles as in loom weaving. No change to the technique 
over time was observed, although one of the Late Archaic fragments (8219-3) was coarser than earlier examples. This particular fragment was made from a broader reed than found in other examples and may simply represent a specific application requiring a stiffer textile. Unfortunately, the inadequate remnants of the active elements of these artifacts did not allow the determination of fabric density.

The earliest South American examples of twining come from Guitarrero Cave, which were recently redated to at least $11,000 \mathrm{BP}$ (Jolie et al. 2011), and from Quebrada Mani in the Pampa del Tamarugal basin (Santoro et al. 2019). The simplicity of twining is deceptive as the technique can be used to create highly elaborate designs. This is exemplified by examples found at Huaca Prieta in Peru, where geometric designs and animal figures were achieved using transposed warp floats, a technique in which elements are added or diverted to create patterns. This technique dates to 4000 BP (Anton 1987; Bird et al. 1985; Emery 1980). In northern Chile, similar twined reed fragments were found at Acha, and similarly worked plant fiber mats were common from at least 8000 years BP (Arriaza 2008; Standen and Santoro 2004).

The Chinchorro are characterized by their distinctive, complex processes for the treatment of the dead (Standen et al. 2017), so unsurprisingly, the vast majority of the twined fragments from Archaic period sites in the archaeological record come from burial contexts. Nevertheless, the interpretation of the function of the open-twined fragments at Caleta Vitor is complicated by research showing other domestic applications for twining, including baskets, cloaks, floor matting, and house construction. Significantly, many of the fibers that were used to fasten the wefts in the twined fragments were spun in a clockwise direction, resulting in a Z-spin, and then they were plied in a counterclockwise direction, giving an S-ply. Just 6 of the 91 camelid threads from the site display S-spin and Z-ply. As with the camelid threads, the cotton threads were mostly Z-spun and S-plied and replied in the Z-direction, with only two threads constructed in the S-spin, Z-ply orientation. This technique appears to be a cultural preference: spinners at other sites in the south-central Andes also favored Z-spun, S-plied threads (Oakland 1986). Using criteria for thread thickness identified by Emery (1980), we found that most of the camelid threads displayed medium to tight twist angles in plying $\left(40^{\circ}-20^{\circ}\right)$ and tight to very tight angles in the initial spin $\left(20^{\circ}-10^{\circ}\right)$. Although thread thicknesses varied between artifacts $(0.3 \mathrm{~mm}-1.8 \mathrm{~mm})$, this attribute appears to be contingent on function. Individual threads were relatively evenly spun and plied, reflective of a well-practiced craft rather than the work of novices. Nevertheless, further refinement is notable in the appearance of the finest threads $(0.3$ $\mathrm{mm}$ thick) in the latest periods. Vegetal thread construction did not achieve the same consistency as camelid thread production, though the $\mathrm{Z} / \mathrm{S}$ orientation was still preferred, with only $17.24 \%$ of threads displaying the $S / Z$ orientation in Formative period units (Supplemental Table 2).

As expected, interlaced camelid fiber textiles were found in the Late Formative period sequences in balanced and warp-facing structures, with a 1:1 tabby weave, along with a fragment of cotton textile, dyes, and warp stripes (Figure 6). Interlaced textiles in Caleta Vitor's Formative period were probably produced on looms with heddles rather than by handpicking, as in earlier looms. This interpretation is based on evidence for interlaced textiles of comparable age from the Azapa Valley (Azapa 70 site), where a similar suite of techniques has been identified, with the addition of some weft-facing structures (Ulloa 2008). According to Ulloa (2008), the tunics and other warp-faced artifacts from Azapa 70 belong to a broad regional textile tradition that stretches from the Azapa Valley to the Loa region (Agüero and Cases 2004). Even though the samples from Caleta Vitor were much smaller and fragmented than those found at Azapa 70, the co-occurrence of 1:1 balanced tabby weaves, warp-striped, and plain warpfaced structures suggest that they belong to the same textile tradition. Despite the lack of extant remains of looms in Chile, scholars have established that the heddle loom (an advanced version of the backstrap loom) was in use in the region during this time. Technical evidence comes from the fineness and regularity of tunics, bags, and other items excavated from the Azapa Valley 


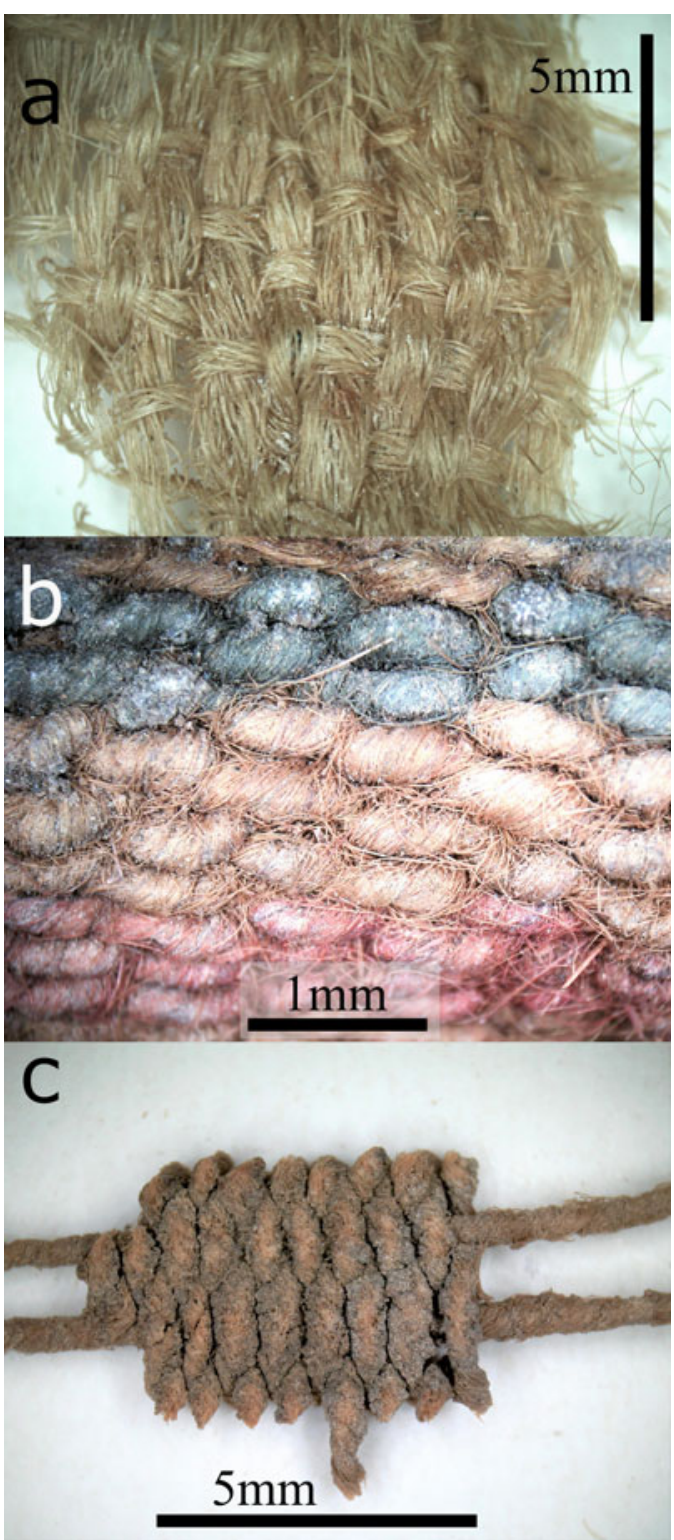

Figure 6. Interlaced fragments: (a) 8231-1 camelid fiber in balanced, 1:1 plain weave; (b) 8347 camelid fiber in warp-striped plain weave; (c) 8233-8 cotton warp-faced plain weave.

combined with evidence of contact with highland groups known to have this technology (Agüero 1995; Agüero and Cases 2004; Ulloa 2008). Significantly, the heddle loom type was common in Peru from 4000 to 3800 BP (DoyonBernard 1990).

\section{Conclusions}

Additional evidence for increased contact between Caleta Vitor and the highlands comes not only from the aforementioned camelid fecal pellets but also the presence of snuff trays. Combined with the archaeological textile evidence, these diagnostic artifacts and camelid pellets confirm greater mobility than previously evidenced throughout the established Chinchorro sphere of interaction, from down the coast to the Loa River area and up to the highlands. Yet the evidence suggests that the weavers of Caleta Vitor were not strongly influenced by highland styles or techniques until the late Intermediate period as shown by the appearance of interlacing and weft-faced structures. These research findings are in accordance with those of Cassman (1997) that showed minimal influence before 1300 BP. Neutron activation studies on pottery clays (Bland et al. 2017) demonstrated that the production of utilitarian pottery at the site remained "stable and local" throughout the Formative and later periods despite external influences. Based on iconography and technical analysis, Ulloa (2008) also detected a similar decline in highland influence among Azapa 70 weavers. Whether these variations in influence reflect differences in migration or trade is difficult to determine, but it is clear that the weavers at Caleta Vitor remained focused on local traditions through to the end of the Formative period.

Acknowledgments. We thank Chris Carter for making his data available for the study and for his valuable comments on this article. We also thank Calogero Santoro not only for his insightful remarks but also for facilitating the laboratory recording in Arica and his translation of our presentation of the data at the Universidad de Tarapacá (2016). The manuscript was greatly improved by comments and suggestions from the reviewers, which we gratefully acknowledge. We also thank Ruperto Nunez for help with translating some of the text, Juliet Meyer for her assistance with preparing the figures, and Paula Ugalde for her crucial logistical support.

We extend our appreciation to the Laboratorio de Arqueología y Paleoambiente, Instituto de Alta Investigación (IAI) de Arqueología y Paleoambiente at the Universidad de Tarapacá for facilitating our research in Chile. The research was supported by an Australian Government Research Training Program (RTP) Scholarship; Australian National University, College of Asia and the Pacific; and FONDECYT (Chilean National Science Foundation Project 1150763 led by Claudio Latorre, Pontificia Universidad Católica of Chile). The map 
of the site was provided by CartoGIS Services, Australian National University.

Data Availability Statement. The collection from the Caleta Vitor archaeological complex is located in Arica, Chile, at the Laboratorio de Arqueología y Paleoambiente, Instituto de Alta Investigación (IAI), at the Universidad de Tarapacá (UTA). Additional data can be requested from the corresponding author (martens.tracy@gmail.com).

Supplemental Materials. For supplementary material accompanying this article, visit https://doi.org/10.1017/laq. 2018.78.

Supplemental Table 1. Fabric Density Scores Calculated as per Cassman (1997:87).

Supplemental Table 2. Summary of Artifact Material Types and Techniques by Archaeological Context.

\section{References Cited}

Adovasio, James M.

1977 Basketry Technology: A Guide to Identification and Analysis. Aldine, Chicago.

1997 Cordage and Cordage Impressions from Monte Verde. In Monte Verde: A Late Pleistocene settlement in Chile, Vol. 2, edited by Tom D. Dillehay, pp. 221228. Smithsonian Institution, Washington, DC.

Adovasio, James M., and Thomas F. Lynch

1973 Preceramic Textiles and Cordage from Guitarrero Cave, Peru. American Antiquity 38:84-90.

Adovasio, James M., and Robert F. Maslowski

1980 Cordage, Basketry, and Textiles. In Guitarrero Cave: Early Man in the Andes, edited by Thomas F. Lynch, pp. 253-290. Acamdemic Press, New York.

Agüero, Carolina

1995 El cementerio "Protonazca" de Pisagua (D), colección Max Uhle. Estudio de la Textilería. Proceedings of the XIII Congreso Nacional de Arqueología Chilena, Hombre y Desierto 2:7-16. Antofagasta, Chile.

Agüero, Carolina, and Barbara Cases

2004 Quillagua y los Textiles Formativos del Norte Grande de Chile. Chungara: Revista de Antropología Chilena [Volumen Especial] 2:599-618.

Anton, Ferdinand

1987 Ancient Peruvian Textiles. Thames and Hudson, New York.

Arriaza, Bernardo T.

1995 Chinchorro Bioarchaeology: Chronology and Mummy Seriation. Latin American Antiquity 6:35-55.

2008 Chinchorro Culture: Pioneers of the Coast of the Atacama Desert. In Handbook of South American Archaeology, edited by Helaine Silverman and William H. Isbell, pp. 45-58. Springer, New York.

Arriaza, Bernardo T., Matthew Doubrava, Vivien G. Standen, and Herbert Haas

2005 Differential Mortuary Treatment among the Andean Chinchorro Fishers: Social Inequalities or In Situ Regional Cultural Evolution? Current Anthropology 46(4):662-671.

Aufderheide, Arthur C., Iván Muñoz, and Bernardo T. Arriaza

1993 Seven Chinchorro Mummies and the Prehistory of Northern Chile. American Journal of Physical Anthropology 91(2):189-201.
Aufderheide, Arthur C., Larry L. Tieszen, Marvin J. Allison, JoAnn Wallgren, and George. J. Rapp

1988 Chemical Reconstruction of Components in Complex Diets: A Pilot Study. Paper presented at the 19th Annual Conference of the Archaeological Association, University of Calgary, Alberta.

Beresford-Jones, David, Alexander Pullen, George Chauca, Lauren Cadwallader, Maria García, Isabel Salvatierra, Oliver Whaley, Víctor Vásquez, Susana Arce, Kevin Lane, and Charles French

2017 Refining the Maritime Foundations of Andean Civilization: How Plant Fiber Technology Drove Social Complexity during the Preceramic Period. Journal of Archaeological Method and Theory 25(2):393-425.

Bird, Junius

1943 Excavations in Northern Chile. Anthropological Papers of the American Museum of Natural History 38(4):179-316.

1963 The Cultural Sequence of the Northern Chilean Coast. In Handbook of South American Indians, Vol. 2, edited by Julian Steward, pp. 587-594. Cooper Square, New York.

Bird, Junius, John Hyslop, and Milica Dimitrijevic Skinner 1985 The Preceramic Excavations at the Huaca Prieta Chicama Valley, Peru. Anthropological Papers of the American Museum of Natural History 62(Pt. 1):1-294.

Bittmann, Bente, and Juan R. Munizaga

1976 The Earliest Artificial Mummification in the World? A Study of the Chinchorro Complex in Northern Chile. Folk 18:61-92.

Bland, Catherine A., Amy Roberts, Rachel S. Popelka-Filcoff, Calogero M. Santoro, Christopher Carter, John W. Bennett, and Attila Stopic

20171500 Years of Pottery: Neutron Activation Analysis of Northern Chilean Domestic Ceramics from Caleta Vitor and Clay Samples from nearby Valley, Coast and Highland Contexts. Archaeometry 59(5):815-833.

Bronk Ramsey, Christopher

2017 Methods for Summarizing Radiocarbon Datasets. Radiocarbon 59:1809-1833.

Carter, Christopher

2016 The Economy of Prehistoric Coastal Northern Chile: Case Study: Caleta Vitor. PhD dissertation, School of Archaeology and Anthropology, Australian National University, Australian Capital Territory.

Cassman, Vicki

1997 A Reconsideration of Prehistoric Ethnicity and Status in Northern Chile: The Textile Evidence. PhD dissertation, Department of Archaeology, Arizona State University, Tempe.

Cassman, Vicki, Nancy Odegaard, and Bernardo T. Arriaza 2008 Chinchorro Twined Shrouds. Paper presented at Textiles as Cultural Expressions conference, Honolulu, Hawaii.

Castro, Victoria

2014 Pre-Hispanic Cultures in the Atacama Desert: A Pacific Coast Overview. In The Chinchorro Culture: A Comparative Perspective; The Archaeology of the Earliest Human Mummification, edited by Nuria Sanz, Bernardo T. Arriaza, and Vivien G. Standen, pp. 25-52. United Nations Educational, Scientific, and Cultural Organization, Paris.

Dillehay, Tom D., Jack Rossen, Thomas Andres, and David Williams

2007 Preceramic Adoption of Peanut Squash, and Cotton in Northern Peru. Science 316:1890-1893. 
Doyon-Bernard, Suzette J.

1990 From Twining to Triple Cloth: Experimentation and Innovation in Ancient Peruvian Weaving (ca. 5000-400 B.C.). American Antiquity 55:68-87.

Emery, Irene

1980 The Primary Structures of Fabrics. Thames and Hudson, Washington, DC.

Gayo, Eugenia M., Claudio Latorre, Calogero M. Santoro, Antonio Maldonado, and Ricardo De Pol-Holz

2012 Hydroclimate Variability on Centennial Timescales in the Low-Elevation Atacama Desert over the Last 2,500 Years. Climate of the Past 8:287-306.

Hogg, Alan G., Quan Hua, Paul Blackwell, Mu Niu, Caitlin Buck, Thomas Guilderson, Timothy Heaton, Jonathon Palmer, Paula Reimer, Ron Reimer, Christian Turney, and Susan Zimmerman

2013 SHCal13 Southern Hemisphere Calibration, 050,000 Years cal BP. Radiocarbon 55:1889-1903.

Jolie, Edward A., Thomas F. Lynch, Phil R. Geib, and James M. Adovasio

2011 Cordage, Textiles, and the Late Pleistocene Peopling of the Andes. Current Anthropology 52(2):285-296.

Keefer, David K., Susan D. DeFrance, Michael E. Moseley, James B. Richardson III, Dennis R. Satterlee, and Amy Day-Lewis

1998 Early Maritime Economy and El Nino Events at Quebrada Tacahuay. Science 281:1833-1835.

King, Charlotte L., Andrew R. Millard, Darren R. Gröcke, Vivien G. Standen, Bernardo T. Arriaza, and Siân E. Halcrow

2018 Marine Resource Reliance in the Human Populations of the Atacama Desert, Northern Chile-A View from Prehistory. Quaternary Science Reviews 182:163-174.

Kuttruff, Jenna, and Mary Strickland-Olson

2000 Handling Archaeological Textile Remains in the Field and Laboratory. In Beyond Cloth and Cordage: Archaeological Textile Research in the Americas, edited by Penelope Drooker and Laurie Webster, pp. 25-50. University of Utah Press, Salt Lake City.

Latorre, Claudio, Ricardo De Pol-holz, Christopher Carter, and Calogero M. Santoro

2017 Using Archaeological Shell Middens as a Proxy for Past Local Coastal Upwelling in Northern Chile. Quaternary International 427:128-136.

Latorre, Claudio, Calogero M. Santoro, Paula C. Ugalde, Eugenia M. Gayo, Daniela Osorio, Carolina SalasEgaña, Ricardo De Pol-Holz, Delphine Joly, and Jason A. Rech

2013 Late Pleistocene Human Occupation of the Hyperarid Core in the Atacama Desert, Northern Chile. Quaternary Science Reviews 77:19-30.

Llagostera, Agustín

1979 9,700 Years of Maritime Subsistence on the Pacific: An Analysis by Means of Bioindicators in the North of Chile. American Antiquity 44:309-324.

McRostie, Virginia B.

2014 Arboricultura y silvopastoralismo en el período Formativo (1.400 a.c.-500 d.C.) de la cuenca del Salar de Atacama. Chungara: Revista de Antropología Chilena 46:543-557.

McRostie, Virginia B., Eugenia M. Gayo, Calogero M. Santoro, Ricardo De Pol-Holz, and Claudio Latorre

2017 The Pre-Columbian Introduction and Dispersal of Algarrobo (Prosopis, Section Algarobia) in the Atacama Desert of Northern Chile. PLoS ONE 12(7):1-15.
Marquet, Pablo A., Calogero M. Santoro, Claudio Latorre, Vivien G. Standen, Sebastián R. Abades, Marcelo M. Rivadeneira, Bernardo T. Arriaza, and Michael E. Hochberg

2012 Emergence of Social Complexity among Coastal Hunter-Gatherers in the Atacama Desert of Northern Chile. Proceedings of the National Academy of Sciences of the United States of America 109:14754-14760.

Muñoz, Iván, Carolina Agüero Piwonka, and Daniela Valenzuela

2016 Poblaciones prehispánicas de los valles occidentales del norte de Chile: desde el período Formativo al Intermedio Tardío (ca. 1.000 a.c.-1.400 d.c.). In Prehistoria en Chile desde sus Primeros Habitantes hasta los Incas, edited by Santiago Editorial Universitaria y Sociedad Chilena de Arqueología, pp. 181-237. Editorial Universitaria, Santiago de Chile.

Núñez, Lautaro, Martín Grosjean, and Isabel Cartajena

2002 Human Occupations and Climate Change in the Puna de Atacama, Chile. Science 298:821-824.

Núñez, Lautaro, and Calogero M. Santoro

2011 El tránsito Arcaico-Formativo en la circunpuna y valles occidentales del Centro Sur Andino:hacia los cambios "neolíticos." Chungara: Revista de Antropología Chilena 43:487-531.

Oakland, Amy

1986 Tiwanaku Textile Style from the South Central Andes, Bolivia and North Chile. Unpublished PhD dissertation, Department of Art History, University of Texas, Austin.

Poulson, Simon R., Susan C. Kuzminsky, G. Richard Scott, Vivien G. Standen, Bernardo T. Arriaza, Iván Muñoz, and Lindsay Dorio

2013 Paleodiet in Northern Chile through the Holocene: Extremely Heavy $\Delta 15 n$ Values in Dental Calculus Suggest a Guano-Derived Signature? Journal of Archaeological Science 40(12):4576-4585.

Rivera, Mario A.

1991 The Prehistory of Northern Chile: A Synthesis. Journal of World Prehistory 5(1):1-47.

2008 The Archaeology of Northern Chile. In Handbook of South American Archaeology, edited by Helaine Silverman and William H. Isbell, pp. 963-977. Springer, New York.

Roberts, Amy, F. Donald Pate, Bianca Petruzzelli, Christopher Carter, Michael C. Westaway, Calogero M. Santoro, Jaime Swift, Todd Maddern, Geraldine E. Jacobsen, Fiona Bertuch, and Francisco Rothhammer

2013 Retention of Hunter-Gatherer Economies among Maritime Foragers from Caleta Vitor, Northern Chile, during the Late Holocene: Evidence from Stable Carbon and Nitrogen Isotopic Analysis of Skeletal Remains. Journal of Archaeological Science 40(5):2360-2372.

Rothhammer, Francisco, and Tom D. Dillehay

2009 The Late Pleistocene Colonization of South America: An Interdisciplinary Perspective. Annals of Human Genetics 73(5):540-549.

Sandweiss, Daniel $\mathrm{H}$.

2008 Early Fishing Societies in Western South America. In Handbook of South American Archaeology, edited by Helaine Silverman and William H. Isbell, pp. 145156. Springer, New York.

Sandweiss, Daniel H., Heather Mcinnis, Richard L. Burger, Asuncion Cano, Bernardino Ojeda, Rolando, Paredes, Maria del Carmen Sandweiss, and Michael D. Glascock 
1998 Quebrada Jaguay: Early South American Maritime Adaptations. Science 281:1830-1832.

Santana Sagredo, Francisca, Julia A. Lee-Thorp, Rick Schulting, and Mauricio Uribe

2015 Isotopic Evidence for Divergent Diets and Mobility Patterns in the Atacama Desert, Northern Chile, during the Late Intermediate Period (AD 900-1450). American Journal of Physical Anthropology 156(3):374-387.

Santoro, Calogero M., Marcelo Rivadeneria, Claudio Latorre, Francisco Rothhammer and Vivien Standen

2012 Rise and Decline of Chinchorro Sacred Landscapes. Chungara, Revista de Antropología Chilena, 44(4): 637-653.

Santoro, Calogero M., Bernardo T. Arriaza, Vivien G. Standen, and Pablo A. Marquet

2005 People of the Coastal Atacama Desert Living between Sand Dunes and Waves of the Pacific Ocean. In Desert People: Archaeological Perspectives, edited by Peter Veth, Mike Smith, and Peter Hiscock, pp. 243-260. Blackwell, Malden, Massachusetts.

Santoro, Calogero M., Eugenia M. Gayo, José M. Capriles, María E. de Porras, Antonio Maldonado, Vivien G. Standen, Claudio Latorre, Victoria Castro, Dante Angelo, Virginia B. McRostie, Mauricio Uribe, Daniela Valenzuela, Paula C. Ugalde, and Pablo A. Marquet

2017a Continuities and Discontinuities in the SocioEnvironmental Systems of the Atacama Desert during the last 13,000 years. Journal of Anthropological Archaeology 46:28-39.

2017b Loco or No Loco? Holocene Climatic Fluctuations, Human Demography and Community Base Management of Coastal Resources In Northern Chile. Frontiers in Earth Science, Quaternary Science, Geomorphology and Paleoenvironment 5:1-16.

Santoro, Calogero M., Eugenia M. Gayo, José M. Capriles, Marcelo M. B Rivadeneira, Bernardo T. Arriaza, Katerine A. Herrera, Valentina Mandakovic, Monica Rallo, Jason A. Rech, Barbara Cases, Luis Briones, Laura Olguín, Daniela Valenzuela, Luis A. Borrero, Paula C. Ugalde, and Claudio Latorre

2019 The Pleistocene Roots of the Atacama Desert's Llama Caravans, from the Pacific Coast to the Tropical Forests. Chungara: Revista de Antropología Chilena in press.

Schiappacasse, Virgilio, and Hans Niemeyer

1984 Descripción y Análisis Interpretativo de un Sitio Arcaico Temprano en la Quebrada de Camarones. Publicación Ocasional, No.40. Museo Nacional de Historia Natural, Santiago, Chile.

Standen, Vivien G.

1997 Traumas en las poblaciones Chinchorro (costa norte de Chile): violencia o situaciones accidentales? Chungara: Revista de Antropología Chilena 29:133-150.
2003 Bienes funerarios del cementerio Chinchorro Morro 1: descripción, análisis e interpretación. Chungara: Revista de Antropología Chilena 35:175-207.

Standen, Vivien G., and Calogero M. Santoro

2004 Patrón funerario arcaico temprano del sitio Acha-3 y su relación con Chinchorro: cazadores, pescadores y recolectores del Desierto de Atacama, costa norte de Chile. Latin American Antiquity 15:89-109.

Standen, Vivien G., Calogero M. Santoro, Bernardo T. Arriaza, and Drew Coleman

2017 Hunting, Gathering, and Fishing on the Coast of the Atacama Desert: Chinchorro Population Mobility Patterns Inferred from Strontium Isotopes. Geoarchaeology 33(2):162-176.

Sutter, Richard

2000 Prehistoric Genetic and Cultural Change: A Bio-Archaeological Search for Pre-Inka Altiplano Colonies in Coastal Valleys of Moquegua, Peru, and Azapa, Chile. Latin American Antiquity 11:43-70.

Tieszen, Larry L., and Michael Chapman

1992 Carbon and Nitrogen Isotopic Status of the Major Marine and Terrestrial Resources in the Atacama. Proceedings of the World Congress on Mummy Studies 1:409-425. Tenerife, Spain.

Uhle, Max

1974 Los Aborigenes de Arica y el hombre Americano. Chungara: Revista de Antropología Chilena 3:13-21.

Ulloa, Liliana

1981a Evolución de la industria textil prehispánica en la zona de Arica. Chungara: Revista de Antropología Chilena 8:97-108.

1981b Estilos decorativos y formas textiles de poblaciones agromarítimas en el extremo norte de Chile. Chungara: Revista de Antropología Chilena 8:109-136.

2001 El Arte de Tejer en los Andes. Ediciones Universidad de Tarapacá, Arica, Chile.

2008 Tunics from the Azapa Valley, Late Formative Period: A New Weaving Tradition in the Lower Valleys. Paper presented at Textiles as Cultural Expressions conference, Honolulu, Hawaii.

Valenzuela, Daniela, Calogero M. Santoro, José M. Capriles, María José, Ronny Peredo, Eugenia M. Gayo, Indira Montt, and Marcela Sepúlveda

2015 Consumption of Animals beyond Diet in the Atacama Desert, Northern Chile (13,000-410 BP): Comparing Rock Art Motifs and Archaeofaunal Records. Journal of Anthropological Archaeology 40:250-265.

Wendrich, Willemina

1991 Who Is Afraid of Basketry. Centre of Non-Western Studies, Leiden University, Netherlands.

Submitted March 5, 2018; Revised August 5, 2018; Accepted November 29, 2018 